\title{
Implementasi Teori Konstruksi Sosial dalam Penelitian Public Relations
}

\author{
Ani Yuningsih
}

ABSTRACT

\begin{abstract}
How far has PR research been conducting in order to simultaneously update the rapid development in the field? The answer for this question will indicate whether or onot PR performance has succeeded in fulfilling its functions among public. Adopting Berger and Luckmann perspective over the construction of social reality, a PR corporate will achieve a new level of existence by the process of habitualization involving an effective pattern of communication. PR role is no more than bridging, managing, and maintaining traditions based on members of community's experiences, and then transforming through the organization.
\end{abstract}

Kata kunci: teori konstruksi, peran humas, habitualisasi

\section{Pendahuluan}

\subsection{Latar Belakang Masalah}

Sejak tahun 1980 an, Public Relations Institute of Australia (PRIA) sebagai lembaga asosiasi public relations di Australia, yang berdiri sejak tahun 1959, dalam setiap konvensi atau diskusi yang diselenggarakannya mendeklarasikan pentingnya meningkatkan profesi PR melalui self education. Bahkan beberapa mahasiswa yang mempelajari public relations di Australia, menggabungkan gelar kelulusan public relations mereka dengan kelulusan di bidang studi lainnya, menjadi double degree, sesuai dengan minat dan arah karier yang ingin mereka capai, seperti dengan ilmu marketing dan manajemen, advertising, journalistic, media studies, hubungan internasional dan sebagainya ( Johnston \& Zawawi, 2004: 18-19). Artinya seseorang yang terjun di dunia profesi public relations, baik sebagai praktisi maupun teoritisi, sudah semestinya mengembangkan kapabilitas dan profesionalitas di bidangnya masing-masing. Bila perlu mempelajari bidang lain yang relevan dengan kebutuhan pekerjaan yang digelutinya.

Stagnasi atau kemandekan yang muncul pada perkembangan suatu profesi, pada umumnya terjadi ketika praktisi maupun teoretisi yang menekuninya kehilangan antusiasme untuk berinovasi dan berimprovisasi dengan keahlian dan keilmuan yang dimilikinya. Dalam hal ini termasuk inovasi dan improvisasi penelitian/riset, yang merupakan esensi perkembangan suatu disiplin ilmu, sehingga strategi dan perencanaan 
komunikasi dalam program public relations menjadi "mandul", atau masalah-masalah yang dihadapi public relations menjadi "imun" terhadap strategi yang ada. Faktor penyebabnya, antara lain, semakin meningkatnya daya kritis khalayak sasaran, dan atau semakin gencarnya pesan-pesan public relations "canggih" dari para pesaing, dalam lingkup lokal maupun global.

Joseph F. Awad dalam bukunya The Power of Public Relations, seperti dikutip Indrawadi Tamin (2004 : 2), antara lain mengemukakan adanya tujuh salah persepsi terhadap humas dalam manajemen, yakni:

(1) Functional Myopia: Ketidakmampuan melihat fungsi Public Relations yang sebenarnya dalam suatu proses manajemen. Persepsi ini terlihat dalam sikap para pengambil keputusan sbb:

(a) Siapa pun dapat melakukan pekerjaan humas, jadi buat apa menggaji orang khusus untuk mengerjakan itu?

(b) Kegiatan PR dilakukan dengan asalasalan

(c) Meletakkan PR dalam posisi rendah dalam organisasi

(d) Menganggap PR hanya sebagai unit Publicity atau Event Organizer

(2) The Faucet Philosophy: Berpaling pada humas kalau lagi saat kritis atau saat diperlukan saja.

(3) The Hysteron Proteron Approach: Menganggap bahwa humas tidak perlu melakukan riset.

(4) Local Anesthesia: Sering menganggap bahwa permasalahan yang timbul dalam organisasi hanya masalah internal yang berdampak lokal. Padahal dengan kemajuan teknologi setiap masalah berdampak luas (internal dan eksternal).

(5) Good News Neuresthenia: Sikap yang bersandar pada "Kita percaya bahwa melalui informasi publik yang lengkap dan padat segala hal akan berjalan positif dan baik".

(6) The One Shot Communication tic. Menganggap berkomunikasi cukup sekali atau seadanya. Padahal kita tahu bahwa pengulangan sangat diperlukan dalam komunikasi.

(7) The shadow Delusion: Sikap yang bersandar pada "Low profile philosophy" (filsafat Low profile).

Beberapa persepsi yang keliru tersebut juga bisa menjadi penyebab datangnya kemandekan profesi public relations. Oleh karena itu, menjadi tugas para profesional untuk segera bangkit dan membenahinya, melalui berbagai aktivitas yang relevan dengan bidang pekerjaannya masingmasing. Bagi seorang dosen, teoretisi, konsultan peneliti atau ilmuwan, tentunya sangat relevan bila memulai aktivitas pembenahan itu dengan membuka wawasan pengembangan riset public relations. Kemudian, menyosialisasikan kepada para mahasiswanya agar juga peka terhadap berbagai perspektif aktual dalam riset di bidang public relations.

Mengacu pada permasalahan di atas, penulis tertarik untuk mengkaji lebih dalam tentang rentang dan perkembangan riset public relations yang terkini, termasuk di dalamnya upaya mengadopsi dan mengimplementasikan paradigma konstruktivis (melalui teori konstruksi sosial Berger dan Luckmann) dalam penelitian public relations.

Seperti halnya jejak para teoretisi public relations terdahulu, adopsi dan implementasi teori-teori dari disiplin ilmu lain, apalagi disiplin ilmu sosiologi sebagai salah satu akar ilmu komunikasi, ternyata dimungkinkan untuk dilakukan para peneliti. Melalui tulisan sederhana ini akan dipaparkan secara ringkas, apa yang dimaksud dengan teori konstruksi sosial, serta bagaimana cara mengimplementasikannya dalam riset public relations.

\subsection{Identifikasi Masalah}

Agar permasalahan yang dikaji dan dianalisis relatif lebih terfokus, maka dijabarkan ke dalam beberapa identifikasi masalah berikut ini :

(1) Bagaimana perkembangan dan rentang penelitian public relations (PR)?

(2) Bagaimana pengaruh paradigma konstruktivis melalui teori konstruksi sosial (Berger dan 
Luckmann) dalam penelitian public relations?

(3) Bagaimana implementasi teori konstruksi sosial dalam riset public relations?

\subsection{Tujuan Penulisan}

Penulisan makalah ini pada dasarnya memiliki beberapa tujuan sebagai berikut:

(1) Untuk mengetahui perkembangan dan rentang penelitian public relations (PR).

(2) Untuk mengetahui pengaruh paradigma konstruktivis melalui teori konstruksi sosial (Berger dan Luckmann) dalam penelitian $p u b$ lic relations.

(3) Untuk mengetahui implementasi teori Konstruksi Sosial dalam penelitian/riset $p u b$ lic relations $(\mathrm{PR})$.

\section{Tinjauan Teoretis}

\subsection{Paradigma Konstruktivis sebagai Landasan Teori Konstruksi Sosial}

Konstruksi sosial (sosial construction) merupakan sebuah teori sosiologi kontemporer yang dicetuskan Peter L. Berger dan Thomas Luckmann. Menurut kedua ahli sosiologi tersebut, teori ini dimaksudkan sebagai satu kajian teoretis dan sistematis mengenai sosiologi pengetahuan (penalaran teoretis yang sistematis) dan bukan sebagai suatu tinjauan historis mengenai perkembangan disiplin ilmu. Oleh karena itu, teori ini tidak memokuskan kepada hal-hal semacam tinjauan tokoh, pengaruh dan sejenisnya, tetapi lebih menekankan pada tindakan manusia sebagai aktor yang kreatif dari realitas sosialnya. (Berger dan Luckmann, 1990: 40-41).

Dalam menjelaskan paradigma konstruktivis, realitas sosial merupakan kontruksi sosial yang diciptakan oleh individu. Individu adalah manusia bebas yang melakukan hubungan antara manusia yang satu dengan manusia lainnya. Individu menjadi penentu dalam dunia sosial yang dikonstruksi berdasarkan kehendaknya. Individu bukanlah korban fakta sosial, namun sebagai mesin produksi sekaligus reproduksi yang kreatif dalam mengkonstruksi dunia sosialnya.
Realitas merupakan hasil ciptaan manusia kreatif melalui kekuatan konstruksi sosial terhadap dunia sosial di sekelilingnya. Max Weber melihat realitas sosial sebagai perilaku sosial yang memiliki makna subjektif. Oleh karena itu perilaku memiliki tujuan dan motivasi. Berger dan Luckmann mengatakan bahwa realitas sosial terdiri dari tiga macam, yaitu realitas objektif, simbolik, dan subjektif. Realitas objektif terbentuk dari pengalaman di dunia objektif yang berada di luar diri individu dan realita itu dianggap sebagai suatu kenyataan. Realitas simbolik merupakan ekspresi simbolik dari realitas objektif dalam berbagai bentuk. Sedangkan realitas subjektif adalah realitas yang terbentuk sebagai proses penyerapan kembali realitas objektif dan simbolik ke dalam individu melalui proses internalisasi (Sudikin, 2002: 201-203).

Teori Konstruksi Sosial Berger dan Luckmann yang tertuang dalam buku The Sosial Construction of Reality : A Treatise in Sociology of Knowledge (1990) ini merupakan proyek bersama yang dikerjakan oleh beberapa sosilolog dan filsufyang telah mulai dirintis sejak tahun 1962-1963. Namun, karena alasan tertentu, beberapa filsuf tidak dapat turut serta dalam penulisan buku ini. Buku ini kemudian hanya ditulis oleh dua ahli sosiologi, yaitu Berger dan Luckmann.

Lewat teori konstruksi sosialnya, Berger dan Luckmann menaruh perhatian pada kajian mengenai hubungan antara pemikiran manusia dan konteks sosial tempat pemikiran itu timbul, berkembang dan dilembagakan. Berger dan Luckmann berpandangan bahwa kenyataan itu dibangun secara sosial, sehingga sosiologi pengetahuan harus menganalisis proses terjadinya hal itu.

Dalam sosiologi pengetahuan atau konstruksi sosial Berger, manusia dipandang sebagai pencipta kenyataan sosial yang objektif melalui proses eksternalisasi, sebagaimana kenyataan objektif mempengaruhi kembali manusia melalui proses internalisasi (yang mencerminkan kenyataan subjektif).

Tugas sosiologi pengetahuan menurut Berger, ialah untuk menekuni segala sesuatu yang 
dianggap "pengetahuan" dalam masyarakat. Jadi, pusat perhatiannya adalah pada struktur dunia akal sehat (commonsense world). Pengetahuan adalah kegiatan yang menjadikan suatu kenyataan menjadi bisa diungkapkan yang berbeda dengan kesadaran.

Kesadaran ialah individu lebih mengenal dirinya sendiri ketika berhadapan dengan kenyataan tertentu. Pengetahuan terkait dengan urusan subjek dan objek yang berbeda dengan diri sendiri, sedangkan kesadaran lebih berurusan dengan subjek yang sedang mengetahui dirinya sendiri (Sudikin, 2002: 204).

Dalam hal ini, Berger mendefinisikan mengenai peran dan hakikat sosiologi pengetahuan ialah mendefinisikan tentang "kenyataan" dan "pengetahuan". Kenyataan sosial lah yang tersirat di dalam pergaulan sosial yang diungkapkan secara sosial melalui komunikasi lewat bahasa, bekerjasama lewat bentuk-bentuk organisasiorganisasi sosial dan sebagainya. Kenyataan sosial ini ditemukan di dalam pengalaman intersubjektif. Sedangkan pengetahuan mengenai kenyataan sosial ialah berkaitan dengan penghayatan kehidupan bermasyarakat dengan segala aspeknya, meliputi kognitif, psikomotorik, emosional, dan intuitif.

Jika Durkheim maupun Weber melihat keterpilahan antara objektivitas dan subjektivitas, maka Berger melihat keduanya sebagai sesuatu yang tidak dapat dipisahkan. Diandaikan bahwa terdapat subjektivitas dan objektivitas di dalam kehidupan manusia dan masyarakatnya (Sudikin, 2002: 205).

Masyarakat ialah sebagai kenyataan objektif sekaligus sebagai kenyataan subjektif. Sebagai kenyataan objektif, masyarakat sepertinya berada di luar diri manusia dan berhadap-hadapan dengannya. Sedangkan sebagai kenyataan subjektif, individu berada di dalam masyarakat itu sebagai bagian tak terpisahkan. Dengan kata lain, individu adalah pembentuk masyarakat dan masyarakat ialah pembentuk individu. Kenyataan sosial itu bersifat ganda dan bukan tunggal, yaitu kenyataan objektif dan kenyataan subjektif. Kenyataan objektif ialah kenyataan yang berada di luar diri manusia, sedangkan kenyataan subjektif ialah kenyataan yang berada di dalam diri manusia.

\subsection{Proses Dialektika Konstruksi Kenyataan Sosial}

Melalui sentuhan Hegel, yaitu tesis, antitesis, dan sintesis, Berger menemukan konsep untuk menghubungkan konsep antara yang subjektif dan objektif itu melalui konsep dialektika, yang dikenal sebagai eksternalisasi, objektivasi, dan internalisasi.

Eksternalisasi ialah penyesuaian diri dengan dunia sosiokultural sebagai produk manusia, objektivasi ialah interaksi sosial dalam dunia intersubjektif yang dilembagakan atau mengalami proses institusionalisasi, dan internalisasi ialah individu mengidentifikasi diri di tengah lembagalembaga sosial atau organisasi sosial di mana individu tersebut menjadi anggotanya.

Dialektika tiga hal ini berjalan secara simultan. Artinya, ada proses menarik keluar (eksternalisasi) sehingga seakan-akan hal itu berada di luar (objektif) dan kemudian ada proses penarikan kembali ke dalam (internalisasi) sehingga sesuatu yang berada di luar tersebut seakan-akan juga merupakan sesuatu yang berada di dalam diri. Masyarakat adalah produk individu sehingga menjadi kenyataan objektif melalui proses eksternalisasi dan individu juga produk masyarakat melalui proses internalisasi.

Dengan memandang masyarakat sebagai proses yang berlangsung dalam tiga momen dialektis yang simultan (eskternalisasi, objektivasi, dan internalisasi) serta masalah yang berdimensi kognitif dan normatif, maka yang dinamakan kenyataan sosial itu adalah suatu konstruksi sosial produk masyarakat sendiri (social constructions of reality) dalam perjalanan sejarahnya di masa lampau, ke masa kini, dan menuju masa depan (Berger \& Luckmann, 1990: 41).

\subsubsection{Masyarakat sebagai Kenyataan Objektif}

Masyarakat dalam pandangan Berger dan Luckmann ialah suatu kenyataan objektif, yang di 
dalamnya terdapat proses pelembagaan yang dibangun di atas pembiasaan (habitualisation), di mana terdapat tindakan yang selalu diulangulang, sehingga kelihatan pola-polanya dan terus direproduksi sebagai tindakan yang difahaminya. Jika habitualisasi ini telah berlangsung maka terjadilah pengendapan dan tradisi. Keseluruhan pengalaman manusia tersimpan di dalam kesadaran, mengendap, dan akhirnya dapat memahami dirinya dan tindakannya di dalam konteks sosial kehidupannya, dan melalui proses pentradisian, akhirnya jadilah pengalaman itu ditularkan kepada generasi berikutnya (Sudikin, 2002: 207).

Untuk menularkan atau transformasi ini, maka salah satu instrumen yang penting ialah bahasa. Bahasa digunakan manusia untuk mengobjektivasikan pengalaman-pengalaman tersebut kepada yang lain. Di sinilah terdapat peranan di dalam tatanan kelembagaan, termasuk di dalam kaitannya dengan pentradisian pengalaman dan transformasi pengalam tersebut.

Dalam realitas objektif terdapat pelembagaan dan legitimasi yang mencakup universum simbolis, yaitu proses objektivasi makna-makna baru (logo, motto, slogan, mitos, jargon) yang berfungsi mengintegrasikan makna-makna yang sudah diberikan kepada proses-proses pelembagaan yang berlainan, fungsinya untuk membuat objektivasi yang sudah dilembagakan menjadi masuk akal secara subjektif.

Mitologi misalnya, selain mempunyai fungsi legitimasi terhadap perilaku dan tindakan, juga menjadi masuk akal ketika mitologi tersebut difahami dan dilakukan. Untuk memelihara universum itu diperlukan organisasi sosial. Hal ini, tak lain, ialah karena sebagai produk historis dari kegiatan manusia, maka semua universum yang dibangun atau dikonstruk secara sosial itu akan mengalami perubahan karena tindakan manusia, sehingga diperlukan organisasi sosial untuk memeliharanya. Ketika pemeliharaan itu dibangun dengan kekuatan penuh, maka yang terjadi ialah status quo (Sudikin, 2002: 208).

\subsubsection{Masyarakat sebagai Kenyataan Subjektif}

Untuk menjadikan masyarakat sebagai kenyataan subjektif atau realitas internal, diperlukan suatu sosialisasi, baik yang primerkepada anak (masa pra-sekolah dan sekolah) atau sosialisasi sekunder-kepada orang yang dewasa (usia dewasa yang sudah memasuki dunia publik) yang berfungsi untuk memelihara dan mentransformasikan kenyataan subjektif tersebut. Sosialisasi selalu berlangsung di dalam konteks struktur sosial tertentu, tidak hanya isinya, tetapi juga tingkat keberhasilannya. Jadi, analisis terhadap sosial mikro atau sosial psikologis dari fenomen-fenomen internalisasi harus selalu dilatarbelakangi oleh sesuatu pemahaman sosial makro tentang aspek-aspek strukturalnya. Pemaduan semacam ini yang secara simultan terjadi di dalam proses eksternalisasi, objektivasi, dan internalisasi.

Dengan demikian, hubungan antara individu dengan institusinya adalah sebuah dialektika (interaktif) yang dieksprasikan dengan tiga moment, yaitu: "Society is human product. Society is an objective reality. Man is sosial product". Dialektika ini dimediasikan oleh pengetahuan yang disandarkan atas memori pengalaman di satu sisi dan oleh peranan-peranan yang memrepresentasikan individu dalam tatanan institusional.

\subsection{Kinerja Public Relations sebagai Pembentuk, Pembangun, dan Pemelihara Citra Lembaga}

Dalam tataran praktis, profesi PR kini sudah sangat diakui dan dibutuhkan keberadaannya. Ruang lingkup pekerjaannya pun sudah sangat beragam, yakni meliputi aktivitas: Communications: melakukan pertukaran fikiran, opini-opini atau pesan-pesan melalui makna visual, lisan maupun tulisan; Publicity; Promotions; Press agentry; Integrated marketing; Issues management; Press Secretary/Public Informations Officer; Public Affairs/Lobbyist; Financial Relations; Community Relations; Internal Relations; Industry Relations: Minority Relations; Media Realtions; Public Diplomacy; Event Management; Sponshorship; Relationship Marketing; Fundraising; dll. ( dalam Johnston \& Zawawi, 
2004: 257-159).

Semua aktivitas PR tersebut pada dasarnya bertujuan membentuk, membangun, dan memelihara citra atau image lembaga/organisasi. Untuk melaksanakan semua aktivitasnya, seorang PR membutuhkan kemampuan managerial yang handal, yang senantiasa mendasarkan keputusannya kepada informasi dan fakta yang akurat dan aktual. Dengan demikian PR membutuhkan riset atau penelitian.

Mengapa PR membutuhkan riset atau penelitian?

Riset adalah tugas esensial dalam public relations, yang digunakan untuk mengidentifikasi pemeliharaan suatu program komunikasi, membantu dalam memantapkan program, memeriksa perkembangan program dan untuk mengevaluasi efektivitasnya. Misalnya, riset dibutuhkan untuk menentukan apakah akan melanjutkan, atau melewati tahap-tahap suatu kampanye. Melalui fokus penelitian tertentu dan teknik-teknik tersendiri seorang PR bisa memutuskan untuk mengubah tahapan-tahapan suatu kampanye. (Seitel dalam Johnston dan Zawawi, 2004 : 138), mengidentifikasi "the continued importance of instinct and intuition in public relations, but states that management requires more (such as) facts and statistics from public relations professionals to show that their efforts contribute not only to overall organizational effectiveness but also to bottom line."

Saat ini, manajemen memperhatikan akuntabilitas. Anggaran yang diinvestasikan dalam aktivitas public relations harus dapat dijamin kebenarannya, dimonitor dan dipertanggungjawabkan. Akuntabilitas ini kerapkali dilakukan melalui penilaian atas prospek pengembangan investasi bagi masa depan suatu produk yang terkait dengan efektivitas dan ketepatan kampanye. Demikian pula halnya dengan organisasi nonprofit mesti memperhitungkan sumber-sumber yang mereka gunakan. Cara terbaik untuk menganalisis berbagai factor tersebut adalah melalui riset public relations.

Strategi manajemen yang efektif tergantung pada keputusan yang tepat, yang berbasis pada informasi-informasi akurat hasil penemuan riset. "The use of research thus positions public relations as a purposive, goal-directed, and problem solving management function " (Broom and Dozier, 1990: 2).

Menurut Pritchitt dan Sherman (1994) dalam Johnston dan Zawawi (2004 : 140), salah satu cara efektif untuk mengamati proses riset PR adalah melalui istilah input, output, dan outcome. "Inputs determine what goes into the project or program, outputs are the actual elements of the program or campaign, and outcomes are the result of those outputs on the target public or audience" . Model input/output/outcome berikut ini dapat digambarkan melalui suatu siklus proses public relations sebagai cara untuk memahami apa yang butuh untuk diteliti dan kapan penelitian harus dilakukan.

Relationship between a model of a PR process and research

Public relations process

Identify issuel

Problem/opportunity

Establish

Or adjust

Organizational

Goals and

objectives

Input

Research into

the organization, situation. Publics

And proposed

Massage and

strategies

Research focus

Methodologies

And

Techniques

formal and informal

Qualitative and

quantitative 
Outcome

Measurement

Of achievements

Evaluate

achievements

Establish

Communication

Goals and

Objectives

Analysis and

Evaluate

activities

Output

Measurement

Of activity

Develop

strategy

Implement

strategy

Proses operasional public relations tentang planning, implementing dan evaluating, menurut Johnston dan Zawawi dapat mengambil beberapa bentuk. Model siklus diatas secara sederhana menggambarkan suatu proses generik, yang mengacu pada tahap-tahap riset model input/output/outcome yang digambarkan melalui lingkaran kedua. Pada pusat dari lingkaran terdapat rentang teknik-teknik riset yang dapat digunakan selama tahap-tahap tertentu atau pada semua tahapan riset.

\section{Pembahasan}

\subsection{Perkembangan dan Rentang Penelitian Public Relations}

Keberhasilan kinerja public relations (PR), akan dipengaruhi oleh seberapa jauh disiplin ilmu tersebut mampu mengembangkan riset-riset mutakhir yang relevan dengan kebutuhan akan informasi yang akurat. Fakta, data, dan informasi yang lengkap dan akurat akan melahirkan planning dan strategi manajemen PR yang efektif.

Penelitian ialah fondasi bagi kebanyakan praktek PR yang baik, para praktisi PR yang tergabung dalam berbagai organisasi profesi PR menyatakan tentang bagaimana sia-sianya membuat keputusan tanpa didukung fakta-fakta. Penelitian mengurangi risiko, menambah kemampuan untuk membuat keputusan-keputusan yang dapat dipertanggungjawabkan, dan memberikan suatu metode untuk menguji kebenaran dari prasangka kita.

Mengacu pada model Pritchitt dan Sherman (1994), maka rentang penelitian PR dapat dikelompokan kepada tiga kategori jenis penelitian, yaitu:

(1) Input Research : melalui riset input, praktisi PR dapat mengetahui masalah-masalah apa dan peluang-peluang apa yang benar-benar ada; apa persepsi-persepsi dan keyakinan-keyakinan publik, dan alat atau metode komunikasi apa yang paling efektif membantu organisasi mencapai tujuan-tujuannya bersama dengan public-publiknya. Riset input memberi informasi yang dibutuhkan untuk strategi dan planning/ perencanaan.

(2) Output Research : melalui riset output, praktisi PR dapat mengumpulkan informasi tentang ketepatan pesan dan isi/kandungan aktivitas, dan kualitas pesan dan presentasi/ penyajian aktivitas. Informasi ini dapat menjadifeedback dalam mengembangkan strategi atau mengimplementasikan tahapan-tahapan yang sesuai untuk mengembangkan pengiriman pesan.

(3) Outcome Research : berguna tidak hanya untuk mengindikasi tingkat kesuksesan dan kegagalan suatu strategi namun dapat menunjukkan bagaimana efektivitas planning dan komunikasi yang sudah dilakukan. Informasi ini dapat digunakan dalam tahap input pada siklus berikutnya.

Perkembangan penelitian public relations, sebagaimana perkembangan pada ranah-ranah ilmu sosial lainnya, kini tidak lagi terbatas pada melakukan penelitian yang bersifat kuantitatif, tetapi juga penelitian kualitatif. Penelitian kualitatif cenderung terbuka, dan biasanya berkaitan dengan suatu penemuan, penggalian data secara bebas dan tak terstruktur. Penelitian kualitatif seringkali digunakan PR dengan tujuan eksplorasi/ 
penjajagan suatu area yang belum dipetakan atau melibatkan subjek-subjek sensitif. Misalnya, untuk menjajaki kebutuhan dan motivasi para anggota/ karyawan, memahami citra organisasi dan budaya organisasi yang dimaknai para anggota, dan lain sebagainya.

Beberapa teknik penelitian kualitatif maupun kuantitatif yang dapat digunakan dalam riset Public Relations (PR), antara lain, adalah:

In-depth Interview: menggali data melalui wawancara secara komprehensif dan detail, untuk menggali pikiran, perasaan, dan sikap yang tersembunyi.

Focus Group: terdiri atas $8-15$ orang yang memiliki karakteristik yang sama, yang berdiskusi secara mendalam tentang masalah-masalah yang actual. Diskusi focus group ini membuat praktisi PR mampu mengumpulkan informasi awal dari target audience tentang pesan-pesan yang komprehensif dan dapat diterima. Teknik ini digunakan saat merintis pilot project study atau melakukan pre test tentang pesan-pesan kunci.

Etnographic Study: penelitian tentang kelompok sosial atau setting budaya tertentu, di mana peneliti mengobservasi langsung dengan berada pada situasi mereka. Penelitian ini bertujuan memperoleh pengatahuan tentang rutinitas keseharian, kebiasaan, dan aspek-aspek yang dipredisksi lainnya dalam kehidupan suatu kelompok atau budaya yang akan dipelajari.

Case Study: Bertujuan memperoleh data tentang praktek-praktek dan pengalamanpengalaman hidup nyata. Digunakan untuk menguji masalah-masalah atau even-even, serta melalukan analisis dan evaluasi tentang aspek positif maupun negatif dari even-even, kampanyekampanye atau program-program lainnya. Hasilnya dapat dipergunakan untuk pertimbangan perencanaan even-even baru. Analysis of Existing Data:

Organizational Culture Study : Digunakan untuk memahami organisasi dalam term persepsi image-nya, gaya manajemen, jalur fungsional, komunikasi dan kebijakan-kebijakan umum yang ada di dalam suatu lembaga atau organisasi.

Feedback Analysis: komplain-komplain (kritik), pujian, saran-saran dan ketidakseimbangan dapat direkam dan dianalisis, dan dimanfaatkan untuk perencanaan komunikasi yang akan datang.

Media Monitoring: meneliti media coverage, jumlah target audience suatu program, dan frekuensi audience menerima pesan yang diprogramkan. Bila digunakan lebih dari satu media, maka the gross rating points (GRP) dari kedua media tersebut dapat dijadikan pertimbangan.

Content Analysis: menganalisis tema dan kecenderungan-kecenderungan dalam transkrip diskusi-diskusi panel, sistematika para praktisi membuat code dan kuantitas isi pesan pictorial maupun verbal, baik dalam bentuk materi cetakan maupun tulisan lainnya. (misalnya menganalisis isi pidato, laporan, leaflet, makalah yang diseminarkan dll).

Benchmark Research: digunakan untuk mengidentifikasi status yang dihadirkan (pencitraan) dalam rentang topik-topik tertentu, seperti sikap atau opini publik sasaran, jumlah media coverage, atau readability (keterbacaan) suatu publikasi.

Environmental Monitoring: pada level organisasi, teknik ini pada tahap proses manajemen strategis, untuk mengidentifikasi lingkup permasalahan. Pada level sosial makro digunakan untuk mengidentifikasi faktor-faktor yang berpengaruh terhadap perusahaan. Scanning dan tracking adalah dua jenis proses yang dapat digunakan dalam penelitian ini. "Scanning involves ongoing observation of trends in the environment, while tracking is the constant monitoring of opportunities or threats in the environment that affect organization" (Johnston \& Zawawi, 2004: 158).

Communication Audit: Pada dasarnya digunakan untuk menganalisis dan mengukur channel komunikasi, pesan-pesan, dan ethos komunikasi pada suatu organisasi, baik secra internal maupun eksternal. Terdiri atas readership 
studies; content analysis, dan readibility studies.

"...readership studies designed to measure the number of people in the target public who read organizational publication and remember the information read; content analysis, designed to measure how the media handle news and other information about the organization; and readibility studies which measure the ease with which the target public reads all written communication from the organization" (Johnston \& Zawawi, 2004: 158).

Corporate Communication Archives : rekaman tertulis tentang kampanye yang disampaikan organisasi dan pengumpulan data tentang publik yang ditargetkan, seperti catatan rinci pertemuan (meeting) dan proceedings, dan bentuk-bentuk komunikasi corporate lainnya.

Testimonials: Penelitian tentang pernyataan lisan maupun tulisan tentang kepuasan dari anggota publik yang dijadikan target.

Expert Review: Teknik yang melibatkan konsultan praktisi baik perorangan maupun organisasi yang berpengetahuan atau ahli untuk memverifikasi, mengubah ataupun membantu mengembangkan komponen yang dibutuhkan dalam suatu program komunikasi PR.

Internet Monitoring: Memantau isi newsgroups online, chat rooms, dan web page bulletin boards, untuk mengidentifikasi dan menganalisis pandangan pihak lain, dan memperoleh informasi lebih jaun sebagai bahan pengembangan dan evaluasi program public relations. Misalnya reading newsgroups; using search engine; using software; dan subscribing to mailing list.

Measurement of online presence: Holtz (1999 : 233) menekankan pentingnya menetapkan tujuan yang terukur, sebelum menjelaskan berbagai cara mengukur dampak dari presentasi/tampilan online perusahaan. Misalnya mengukur dampak aktivitas web dalam kampanye terintegrasi (integrated campaign), perilaku publik, dll.
Advertising Value equivalents (AVEs): "this technique involves placing a value on the media coverage obtained by calculating what the space would have cost in advertising terms". (Johnston \&Zawawi, 2004: 159).

Secondary Information Sources: studi kepustakaan dapat digunakan untuk mengumpulkan data yang dibutuhkan, baik perpustakaan pribadi, publik, akademik, maupun pustaka para spesialis (Johnston \& Zawawi, 2004: 155-159).

Melalui paparan tentang jenis-jenis teknik penelitian kualitatif maupun kuantitatif yang dapat digunakan dalam disipilin ilmu public relations, diharapkan dapat diperoleh gambaran rentang penelitian PR. Dengan demikian, para mahasiswa yang sedang mengkaji masalah-masalah PR dan sedang melakukan penelitian dapat diarahkan untuk mengacu kepada teknik-teknik tersebut.

\subsection{Pengaruh Paradigma Konstruktivis terhadap Penelitian di Bidang Public Relations}

Ketika menggunakan metode kualitatif, penelitian di bidang public relations juga tidak terlepas dari pengaruh perspektif-perspektif teoretis tertentu. Perspektif teoretis ini dibutuhkan dalam riset $\mathrm{PR}$, karena teori dapat membimbing pemikiran kita untuk memperoleh peta jalan secara imaginer yang dapat digunakan untuk membantu pemahaman lebih mendalam. Berfikir secara teoritis artinya menggunakan satu set asumsi tentang bagaimana dunia berjalan dalam keteraturan yang dapat diprediksi dan membuat kesimpulan tentang apa yang sedang terjadi. Pendekatan-pendekatan teoretis mampu mengembangkan wawasan melalui pertanyaan-pertanyaan yang dikembangkan tentang berbagai event alamiah, dan proses-proses yang terjadi dan cara menganalisisnya.

Bermacam perspektif teori yang digunakan untuk memahami dan membahas suatu persoalan yang sama akan mengacu pada asumsi-asumsi yang sedikit berbeda. Ketika PR didekati melalui perspektif teori tertentu, maka asumsi dan 
pendekatan yang digunakan pun akan terkait dengan perspektif tertentu pula. Bisa terjadi teori lain yang menggunakan asumsi yang berlainan akan menganggap pandangan/perspektif tersebut sebagai impossible atau bahkan jadi bahan tertawaan.

Mengapa penting untuk memahami PR dari berbagai perspektif teori?

Karena bila suatu fenomena hanya didekati melalui perspektif yang terbatas, akan membatasi pula makna "kedalaman" dan "keluasan" atas fenomena itu pada diri peneliti.

Mengamati perkembangan penelitian saat ini, kebanyakan teoretisi PR meminjam/ mengimplementasikan berbagai teori dari disiplin yang berbeda. Beberapa contoh misalnya teori sistem dipinjam dari disiplin sosiologi dan organisasi, agenda setting dipinjam dari dispilin komunikasi, pendekatan "relationship management" ; teori situasional dari James Grunig dan Todd Hunt, Teori tentang opinion, attitude, dan belief, teori retorika, teori audience and media effect, sosial learning theory, sosial exchange theory dan lain sebagainya.

Sebagaimana halnya implementasi pendekatan-pendekatan semiotika dan teori-teori kritis Habermas juga mulai banyak digunakan dalam penelitian public relations, paradigma konstruktivis, khususnya melalui teori konstruksi sosial, juga bisa digunakan dalam penelitian public relations. Pengaruh paradigma konstruktivis bisa jadi akan cukup besar pada penelitianpenelitian public relations di masa mendatang, mengingat hakikat kinerja dan fungsi public relations itu sendiri sebagai keseluruhan upaya membangun citra suatu lembaga/organisasi di mata khalayak sasaran. Konstruksi citra suatu lembaga/organisasi, merupakan realitas yang bersifat ganda. Bila kita menggunakan perspektif teori konstruksi sosial Berger dan Luckmann, maka bangunan realitas "citra" pun terbentuk melalui proses yang berlangsung dalam tiga momen dialektis yang simultan eksternalisasi-objektivasiinternalisasi.

Citra sebagai realitas sosial berdimensi kognitif dan normatif, dan merupakan produk masyarakat sendiri (sosial constructions of reality) dalam perjalanan sejarahnya di masa lampau, ke masa kini, dan menuju masa depan. Promosi, publisitas, event management, community relations, dan berbagai aktivitas public relations seperti telah dikemukakan pada sebelumnya, pada dasarnya merupakan realitas simbolik dan proses objektivasi makna-makna yang ingin disampaikan organisasi/perusahaan agar diterima dan diinternalisasi oleh khalayak sasaran. Dengan demikian, melalui perspektif teori konstruksi sosial, para peneliti di bidang public relations dapat memperoleh cara pandang lain untuk menilai proses operasional kinerjanya, tidak hanya dari sudut pandang organisasi/perusahaan (penelitian kuantitatif), namun juga dari sudut pandang khalayak sasaran (penelitian kualitatif).

\subsection{Implementasi Teori Konstruksi Sosial dalam Penelitian Public Relations}

Sebagaimana telah dikemukakan sebelumnya, masyarakat dalam pandangan Berger dan Luckmann ialah suatu kenyataan objektif, yang di dalamnya terdapat proses pelembagaan yang dibangun di atas pembiasaan (habitualisation), di mana terdapat tindakan yang selalu diulangulang sehingga kelihatan pola-polanya dan terus direproduksi sebagai tindakan yang difahaminya. Jika habitualisasi ini telah berlangsung maka terjadilah pengendapan dan tradisi.

Mengadopsi pandangan Berger dan Luckman tersebut, organisasi/perusahaan di mana PR bekerja dapat dipandang sebagai suatu kelompok masyarakat yang merupakan kenyataan objektif, maka di dalamnya terdapat pula proses habitualisasi dengan jalan membangun pola-pola komunikasi orgsanisasi yang efektif. Pesan-pesan komunikasi organisasinya itu sendiri bisa merupakan pesan verbal, visual, maupun nonverbal, seperti visi, misi, logo, slogan, tradisi, dll. Peran PR adalah menjembatani dan mengelola dan memelihara pentradisian pengalaman para anggota organisasi dan transformasi pengalaman tersebut, melalui organisasi yang dikelolanya.

Pelembagaan dan legitimasi yang mencakup universum simbolis, yaitu proses objektivasi 
makna-makna baru (logo, motto, slogan, mitos, jargon) yang berfungsi mengintegrasikan maknamakna yang sudah diberikan kepada proses-proses pelembagaan oleh PR, fungsinya untuk membuat objektivasi yang sudah dilembagakan menjadi masuk akal secara subjektif. PR dapat mengetahui bagaimana proses ini berlangsung melalui penelitian dengan perspektif teori konstruksi sosial.

Untuk membangun organisasi/ perusahaan sebagai kenyataan subjektif atau realitas internal, diperlukan suatu sosialisasi untuk mentransformasikan kenyataan subjektif tersebut. Sosialisasi selalu berlangsung di dalam konteks struktur sosial tertentu, tidak hanya isinya, tetapi juga tingkat keberhasilannya. Jadi, praktisi dan teoretisi PR perlu melakukan analisis terhadap sosial mikro atau sosial psikologis dari fenomenfenomen internalisasi harus selalu dilatarbelakangi oleh sesuatu pemahaman sosial makro tentang aspek-aspek strukturalnya. Pemaduan semacam ini yang secara simultan terjadi di dalam proses eksternalisasi, objektivasi, dan internalisasi, yang dapat difahami melalui penelitian.

Dengan kata lain, implementasi teori konstruksi sosial dalam penelitian public relations dapat dilakukan untuk memahami proses terbangunnya citra, opini, corporate culture, brand image, public loyalty, dan lain sebagainya, pada diri khalayak sasaran. Proses eksternalisasi, objektivasi, dan internalisasi dapat ditelusuri dan dikaji melalui penelitian ini, sehingga tahap demi tahap akan dapat dipantau, dievaluasi tingkat efektivitasnya untuk merumuskan strategi dan perencanaan program yang tepat.

\section{Penutup}

\subsection{Kesimpulan}

(1) Perkembangan penelitian public relations, sebagaimana perkembangan pada ranah-ranah ilmu sosial lainnya, kini tidak lagi terbatas pada melakukan penelitian yang bersifat kuantitatif, tetapi juga penelitian kualitatif.

Mengacu pada model Pritchitt dan Sherman, maka rentang penelitian PR dapat dikelompokkan kepada tiga kategori jenis penelitian, yaitu:

(a) Input Research: Riset input memberi informasi yang dibutuhkan untuk strategi dan planning/perencanaan.

(b) Output Research: melalui riset output, praktisi PR dapat mengumpulkan informasi tentang ketepatan pesan dan isi/kandungan aktivitas, dan kualitas pesan dan presentasi/ penyajian aktivitas.

(c) Outcome Research: berguna tidak hanya untuk mengindikasi tingkat kesuksesan dan kegagalan suatu strategi namun dapat menunjukkan bagaimana efektivitas planning dan komunikasi yang sudah dilakukan. Informasi ini dapat digunakan dalam tahap input pada siklus berikutnya.

(2) Pengaruh paradigma konstruktivis bisa jadi akan cukup besar pada penelitian-penelitian public relations di masa mendatang, mengingat hakikat kinerja dan fungsi public relations sebagai keseluruhan upaya membangun citra suatu lembaga/ organisasi di mata khalayak sasaran. Konstruksi citra suatu lembaga/ organisasi, merupakan realitas yang bersifat ganda. Bila kita menggunakan perspektif teori konstruksi sosial Berger dan Luckmann, maka bangunan realitas "citra" pun terbentuk melalui proses yang berlangsung dalam tiga momen dialektis yang simultan eksternalisasiobjektivasi-internalisasi.

(3) Implementasi teori konstruksi sosial dalam penelitian public relations, dapat dilakukan untuk memahami proses terbangunnya citra, opini, corporate culture, brand image, public loyalty, dan lain sebagainya, pada diri khalayak sasaran. Proses eksternalisasi, objektivasi, dan internalisasi dapat ditelusuri dan dikaji melalui penelitian ini, sehingga tahap demi tahap akan dapat dipantau, dievaluasi tingkat efektivitasnya untuk merumuskan strategi dan perencanaan program yang tepat.

\subsection{Saran}

(1) Para praktisi, maupun teoretisi profesi public relations sebaiknya selalu mengakses 
perkembangan metode dan teknik-teknik penelitian yang mutakhir, karena manajemen public relations yang baik adalah yang didukung oleh fakta dan informasi yang aktual dan akurat.

(2) Berbagai perspektif teoretis, baik dalam ranah kuantitatif maupun kualitatif, dapat diadopsi bagi kepentingan riset public relations. Jadi, kreativitas dan daya inovasi para teoretisi sangat diperlukan untuk melakukan terobosan baru, yang pada gilirannya akan memberikan manfaat bagi para praktisi ketika menyusun strategi di lapangan.

(3) Perlu dibuatkan peta atau payung penelitian dalam disiplin ilmu komunikasi, khususnya bidang kajian PR, untuk mengarahkan penelitian para dosen dan mahasiswa, sehingga tujuan penelitian untuk pengembangan ilmu tercapai, serta dapat dilahirkan strategi-strategi baru yang sesuai dengan tantangan dan kebutuhan. Pada akhirnya diharapkan tercipta link \& match antara teoretisi dan praktisi public relations.

\section{Daftar Pustaka}

Berger.Peter L. and Thomas Luckmann. 1990. Tafsir Sosial atas Kenyataan , terj. Hasan Basari dari The Sosial Construction of Reality: A Treatise in the Sociology of Knowledge. Jakarta: LP3S.

Johnston, Jane. And Zawawi, Clara. 2004. Public Relations Theory and Practise, Sydney: Allen \& Unwin.

Tamin, Indrawadi. 2004 The Myth and Practice of Public Relations, makalah. Jakarta: BPP Perhumas.

Sudikin, Basrowi. 2002. Metode Penelitian Kualitatif Perspektif Mikro. Surabaya: Insan Cendekia Surabaya.

Waters, Malcolm. 1984. Modern Sociological Theory, London, Thousand Oaks, New Delhi: Sage Publications. 